\title{
Sunbeams and Sugar Cane: An Anti-Oedipal Interpretation of Mansfield Park
}

\author{
Robert Tindol \\ Guangdong University of Foreign Studies
}

\begin{abstract}
Jane Austen's 1814 novel Mansfield Park is noteworthy for its brief and ambivalent mention of slavery in the British colonies. Edward Said r notably argued that the novel demonstrates a dismissive attitude toward, slavery, while other critics have argued that the stern treatment which the novel's heroine, Fanny Price, receives at the hands of her extended family is itself similar to slavery. At least one critic has written that the novel can $k$ viewed with the Anti-Oedipal work of Gilles Deleuze and Felix Guattari in mind. The purpose of this paper is to extend the Anti-Oedipal argument further by contextualizing it within the adamant refusal of Fanny Price to bend to her family's wishes that she wed a suitor whom she distrusts. Thus, Anti-Oedipal reading of Mansfield Park explains the family dynamics of the Bertrams and their enablers, the unorthodox reaction of the young lady whom they unsuccessfully attempt to dominate, and perhaps hints at the larger view of British society. If Fanny Price's situation is indeed an analogu to slavery, then her "liberation" is also an indication that Austen may have viewed slavery as an inherently unstable institution.
\end{abstract}

One of the most influential readings of Jane Austen's 1811 novel Mansfield Park is that of Edward Said, which focuses on the seemingly minor detai that the Bertram family owns property in Antigua at a time when slaves are still being used in the West Indian island's sugar plantations, and that various members of the family are seemingly complacent about the fact. Said's analysis, which is also one of the most memorable literary interpretations in his 1994 work Culture and Imperialism, has been criticized by those who would defend Austen against accusations that she was relatively indifferent to the issue of slavery. ${ }^{[1]}$ However, the issue is ambiguous because the novel is simply not transparent in its attitude toward slav - not in the outlook of the characters and certainly not in the novel's position toward slavery as a social institution. The sparse mention of Antigua ar the lone reference to slavery make it difficult to infer the unspoken opinions of the main character Fanny Price, which is precisely what we are forcec to do if we wish to broach the topic at all.

The easy solution is either to credit the Mansfield Park characters (or Fanny, at least, and probably her sympathetic cousin Edward as well) with a charitable opposition to slavery that was as forceful as the times would allow, or else to accuse them of viewing slavery as a necessary evil best ignored if they did not wish to imperil their comfortable lifestyles. And because the Said controversy shows that little can additionally be said about 1 direct exchanges in the novel concerning slavery, I propose a search of other details in Fanny Price's story that will help illuminate her unspoken feelings on the subject. Specifically, I would like to focus on Fanny's adamant refusal to accept the marriage proposal of the immature and morally la Henry Crawford, in light of the work of the French postmodernist philosophers Gilles Deleuze and Felix Guattari. My argument is that Fanny's decisii may seem illogical, perplexing and even selfish to her family, but is nonetheless in keeping with the type of familial/social protest addressed by Deleuze/Guattari in their celebrated 1977 work Anti-Oedipus. Taken in this context, Fanny can be credited with a third alternative that is brightly separated from both anti-slavery sentiments and of easy acquiescence as a means of enriching the ruling class. The result, I believe, will defend Sai against a purported misreading on his part that has been alleged by various critics, but at the same time will be a rejection of any notion that Mansfi Park represents a grudging acquiescence in slavery as a social institution. To wit, I argue that Fanny's "third way" is a recalcitrance that reflects the inherent instability of slavery which should have been apparent to anyone in the early nineteenth century. She balks, but does so because she understands at some level that the institution is hopeless, just as she instinctively understands that marrying the immature Henry Crawford would be just as doomed to ultimate failure. Further, I argue that her attitude is foreshadowed by many seemingly incidental references to household servants and staff that often include equally incidental details about the relationships between the family and their hired help.

An Anti-Oedipal reading is especially appropriate for the very reason that it circumvents the possibility of being shoe-horned by two alternative pathways. And though the general title of Deleuze/Guattari's two volume work is Capitalism and Schizophrenia, it is important to stipulate at the out: that an Anti-Oedipal interpretation in no way assumes insanity or even slight mental imbalance on the part of the characters or author. Rather, AntiOedipus draws much of its potency in the interpretation of certain works of literature from its background in the turbulent 1960s - particularly the M: 1968 protests that paralyzed much of France for a period of time and flummoxed the traditional anti-establishment figures (oxymoron quite deliberat who thought that a Marxist orientation should be the political and spiritual home of anyone dissatisfied with the status quo. The Deleuzian/Guattaria expert lan Buchanan begins his guidebook on Anti-Oedipus with this insight, and for good reason: the events of May 1968 indeed heralded a new order, but at the same time demonstrated the high likelihood that history would merely repeat itself and that a new order would not be permanently established. As Buchanan explains, Deleuze and Guattari eventually reached the conclusion that the issue had to do with the manifestation of huma desire itself and with the manner in which desire is impacted by social institutions (8).

What does this have to do with Fanny Price's rejection of Henry Crawford in Mansfield Park? The answer is that her doing so was a bit "crazy" by th standards of her day, and certainly by the acquiescence expected of her by an extended family that considered her to be a social inferior. ${ }^{[2]}$ The nov involves the niece by marriage of Thomas Bertram, a powerful baronet by birth and husband of Fanny's maternal aunt. The very first paragraph of tr novel, in fact, assures the reader that Lady Bertram "married up" by securing a husband who would normally not be enticed by the 7,000 pounds th she brought into the marriage by dint of her own familial inheritance. Fanny's second maternal aunt, the dreadful Mrs. Norris, presumably had something similar at her disposal when her own time came to seek a husband, but did little better than marrying a clergyman who died and left her 1 
become a sort of "chief of staff" for the Bertram servants and mentor-of-sorts to her nieces and nephews. The third sister, Fanny's mother, did most poorly of all with her familial inheritance, managing only to marry a lieutenant in the marines who is coarse of character and ever-willing to bend his elbow at the nearest pub. Fanny, in fact, joins her relations in Mansfield Park at the age of 10, following the addition of yet another sibling to her financially-stressed Portsmouth family. Her own mother and father seemed relieved to reduce the table-count by one, and except for her eldest brother William, no one seems to miss her at all. ${ }^{[3]}$

Fanny may be a close blood relative of the Bertram children, comprising brothers Tom and Edmund and sisters Maria and Julia, but she is habitually treated by several members of the family like an inferior, particularly by her Aunt Norris. Assured repeatedly that she should remember her place anc circumstances, Fanny grows up in a situation that positions her in an odd half-world in which she is not of the highest familial status, but nonetheles is of higher status of the servants and even of the contractors who rent the property of Sir Thomas for their own livelihoods. And though none of the Bertrams - least of all Aunt Norris - expect any young suitor of means to find Fanny desirable, all are more than willing to see her married away for financial advantage. As the text makes clear, Fanny is every bit the intellectual and physical equivalent of her cousins, even though she lacks their confidence, and is quite capable of assuming the demeanor and deportment of a young scion of the ruling class.

Fanny's provisional status is somewhat analogous to the situation of slaves in the British colonies, as many critics have argued, ${ }^{[4]}$ and the analogy is further underscored by the constant references Austen makes throughout the novel to the servants. Although many if not most characters in Austen six novels have servants at their disposal, I think a close count would reveal that Mansfield Park is particularly dense not only in the number of direct and indirect references to both the servants and to the services they perform, but also to the manner in which certain members of the family (and ev close family associates such as Henry Crawford) interact with the staff. These references include the numerous asides such as Henry Crawford's "taking from the servant" Fanny's shawl so that he can put it around her shoulders (202), to passing comments such as Mrs. Norris's having "some orders for Nanny" (259), to Crawford's "own two men" pushing his carriage back to the stables (176). There are at least 80 such references that I count, including a hearty number of passing observations about the guidance and evaluation of the servants, such Mrs. Norris's "experiencing som $\epsilon$ evil from the passing of the servants behind her chair" (191), and her ongoing vigilance by dint of which "more than one bad servant had been detected" (149).

Moreover, the attention to the quality of the servants is not limited to Mrs. Norris, and in fact becomes even more pointed and acute when Fanny vis her rambunctious Portsmouth family late in the novel. The family is by no means well to do, but nonetheless is able to employ two servants who receive constant scrutiny, even from five-year-old Betsy, who is enjoined by her and Fanny's mother to "run to the kitchen, and see if Rebecca has $F$ the water on" (303). And lest we surmise that Fanny is secretly a champion of social equality, we learn that Rebecca's assistant possesses an appearance so modest as to inform Fanny "to her great surprise, that she had previously seen the upper servant" (308). Fanny seems startled by the fact that her Portsmouth's family servants shout out a "halloo" from the kitchen (315), and does not offer any defense when her mother routinely discusses "the badness of the Portsmouth servants" (328). Such minor but telling details, as well as a few other asides such as her earlier acquiescence in her brother William's plan for the two to purchase a property with his naval "prize money," preclude any notion that Fanny is a tirele champion of the underdog. ${ }^{[5]}$ She may be quite benign in her treatment of the hired help, but there is no real textual evidence that she has any passi to fight for social equality, either in the pleasant countryside of southern England or in the sweat-shops of Antigua. Her only "hot-button issue" seen to be a defense of the traditional role of the clergy when Henry's sister Mary derides those rituals (74-75), and again later in the novel when Crawforc himself offers his wisdom on the topic of the church liturgy (273-4).

In sum, this is an Austen novel that is not Upstairs Downstairs in its egalitarian treatment of family and staff, but nonetheless one that constantly dra momentary attention to the relationship between owner and servant. What I argue is that these minor and always inconsequential interactions with $t$ hired help provide a very indirect means of commenting on the situation of a class of servants in Antigua whom we never see. Furthermore, I argue that these interactions highlight the fact that the problems in Antigua can be assumed to be the result of labor interactions. If proper care and maintenance of the hired help should merit a bit of concern to keep the Mansfield Park operations running smoothly, then surely the same must be $t$ case for whatever industry Thomas Bertram maintains in Antigua as part of the family livelihood.

Finally, it should be pointed out that Fanny is an additional financial concern at a time when the family fortune is suffering reversals in part because c the Antiguan property. Thus, the matter of her being married off to an individual of means and the resolution of the Antiguan matter are at least fisca connected. At any rate, one may assume at least three trajectories for the plot elements in light of the monetary problems associated with the Antiguan property and the pressure on Fanny to accept her proposal of marriage: (1) compliance with the family who wishes Fanny to engage in a profitable marriage with a man of means; (2) rejection of the family's desires and subsequent truncation from the family orbit; or (3) rejection of the family's desires and subsequent attempt to carry on as if nothing has happened. The first option is clearly the financially preferable one for all concerned, because the Bertram estate will be empowered by a new influx of capital (Sir Thomas apparently never promising Crawford any sort of dowry or compensation, as he would in the case of his own daughters). Assuming that Bertram's sons Tom and Edward also marry well (in other words, marry young women of the landed gentry), and given that men at the time assumed their wives' property upon marriage, the Bertram estate has nothing to lose financially, and everything to gain. Fanny will not cost the family a cent, and because Henry Crawford is an orphan with fairly loo connections to his elder sister with whom he lives, preferring to spend his time with the Bertram children whenever possible, one can assume that a marriage would bring only material advantage for the Bertram family in the future.

The second scenario is one in which Fanny rejects Henry Crawford's marriage proposal, and then takes the logical course of withdrawing from the family. Thereby, she would be expected in this scenario to retreat from the family in precisely the same way that she would have nothing further to $d$ with Crawford himself. Presumably she would go back to Portsmouth to live with her nuclear family, dysfunctional as they might be, and all financial relations with the Bertrams would be severed forever. This, in fact, is very similar to the eventual fate of Maria Bertram, who marries a dull but wealtr man of substantial inheritance in part to please her family, but later abandons her husband to take up with the jilted Henry Crawford. Thoroughly 
scandalized, the Bertrams cease all interactions with Maria, and we last see her absconding to another "country" (part of England) with Aunt Norris, who has also finally lost face with Thomas Bertram. Maria and Aunt Norris will get along financially, considering that Thomas Bertram has vowed the his daughter will not suffer deprivations, but neither will enjoy her former status in Bertram financial orbit.

The third scenario - the one that actually takes place in the novel -- would be the most unlikely of all under normal circumstances, for it is simply based on the fact that Fanny Price doesn't wish to marry her suitor, and is unable to provide a convincing argument for not doing so. This third scenario is the crux of the Anti-Oedipal interpretation, and as such will require a somewhat lengthy explication in this paper. But it might be helpful a this point to revisit the question of why Oedipus is a relevant myth in the case of Fanny. According to Deleuze/Guattari, modern family dynamics are based on a socialization that steers individuals on a straight and narrow path. The worst-case scenario of failure is the story of Oedipus, who killed $r$ father and married his mother. The message to be understood by young individuals being socialized properly is that noncompliance can have bad consequences. The moral of the story, then, is that it is better to keep one's natural desires in check rather than risk social and familial chaos. Thus, acquiesce in the family's wishes is perfectly okay and in fact ideal; to reject the family ends the relationship immediately, although circumstances me sometimes call for an individual to act in a "bad" way; but to simply refuse to play the game is a bit crazy. This is where my own reading departs fror that of Katerina Kitsi-Mitakou, who sees in her own Anti-Oedipal reading of Mansfield Park Fanny's recalcitrance and other related plot elements “as the only possibly way of preserving order" (117). Although Kitsi-Mitakou is entirely correct in proposing an Oedipal substructure in Fanny's indoctrination as a family member, there may be other motives than tying up unruly plot ends when the issue involves slavery.

Despite the ambiguity of the slave issue in the novel, the assumption that Sir Thomas is a dynamic character who benefits from newly acquired knowledge is a fairly safe one. When he discovers that his own children have blithely adopted behaviors that he considers morally shocking, he adm to himself that he perhaps could have done a better job of raising them if he had himself possessed certain other values (372). By inference we can assume that Sir Thomas is a man who understands that the ruling class must make certain concessions if it wishes to continue its comfortable lifestyle built on the exploitation of free or cheap labor.

However, Sir Thomas's attitude is ambiguous at best, and this ambiguity is a primary reason that various critics have wished to dispute or at least qualify Edward Said's interpretation, which keys on the lone passage in Mansfield Park that explicitly mentions slavery. Here it is helpful to quote the exchange between Fanny and Ecward soon after Sir Thomas's abrupt return from Antigua:

'Your uncle is disposed to be pleased with you in every respect; and I only wish you would talk to him more. -You are one of those who are too silent in the evening circle.' / 'But I do talk to him more than I used. I am sure I do. Did not you hear me ask him about the slave trade last night?' / 'I did - and was in hopes the question would be followed up by others. It would have pleased your uncle to be inquired of farther.' / 'And I longed to do it - but there was such a dead silence! And while my cousins were sitting by without speaking a word, or seeming at all interested in the subject, I did not like - I thought it would appear as if I wanted to set myself off at their expense, by showing a curiosity and pleasure in his information which he must wish his own daughters to feel.' (157)

Said's controversial interpretation of this passage assumes that privileged members of upper-crust British society such as the Bertrams are complacent in their attitudes toward slavery because ignoring the issue works to their financial advantage and ultimately to the advantage of the British Empire. The "dead silence," to Said, is thereby political in nature.

Thus, Sir Thomas may be the moral center of Mansfield Park, but we are still plagued by the question of whether this moral center is unambiguously good or merely expedient. Does Sir Thomas really favor the right of his children to follow their hearts, or merely wish that they had been better instructed so as to comport themselves more appropriately in loveless marriages? By extension, Sir Thomas may really oppose slavery, but he also may wish merely to enact certain cosmetic changes so that slavery can continue to support the lifestyles of the British elite, but in a less controversi and confrontational manner. By contrast, if Fanny Price is the moral center of the novel, then an Anti-Oedipal interpretation of her actions points the way to a fresh approach to the question of the "dead silence." With this I will turn to a discussion of the novel in an Anti-Oedipal context.

Considering that the overall title of Deleuze/Guattari's two-volume work is Capitalism and Schizophrenia, one naturally assumes that a revisiting of th economic circumstances of the British society that Austen writes about is an efficacious point of departure. One reason that the Anti-Oedipal work enjoys such widespread influence is that it so convincingly describes the economic world that we inhabit in the second decade of the twenty-first century. While the global economy has not mutated into the post-capitalist scenario predicted by Karl Marx, his descriptions of the capitalist proces itself continue to have implications for many areas of human endeavor, including literature. In the case of Anti-Oedipus, one of the interesting mann $\epsilon$ in which nonconformity coincides with economic exigency is in the way in which individuals choose either to follow their inborn inclinations or yield social forces that incessantly insist that they avoid doing so.

To quote Deleuze/Guattari, "[w]hat the schizophrenic experiences, both as an individual and as a member of the human species, is not at all any ont specific aspect of nature, but nature as a process of production" (Deleuze and Guattari 3). What this means is that we have been socialized to take c complacent roles in society according to its own needs, even though these roles may run quite counter to our natural inclinations. "Production" for $t$ individual who has somehow managed to break free of these devices will thus very likely be distinctly different from the social production of which $n$ partake by dint of our conformity. The goal of an Anti-Oedipal reading of Mansfield Park, then, is to question whether Fanny Price's reticence is worl changing. By simply not participating in the continuation of the Bertram family empire (or at least for the moment), does she indirectly do her small part in subverting a society of privilege propped on the backs of slaves? If so, is Sir Thomas really transformed by the encounter, or merely persuadi that he once again needs to adjust his attitude toward his laborers if he wishes to wrest the maximum capital benefit from them? Obviously, we are squarely in the domain of the economic, and a brief overview of the historical particulars is helpful. 
I claim absolutely no originality in arguing that the economic circumstances of the early nineteenth-century British landed gentry should be reviewed make sense of Mansfield Park's attitude toward slavery. In fact, those wishing to investigate the economics of the Bertram family have a wealth of already-published materials at their disposal. In addition, the many glossed versions of Austen's novels sometimes contain helpful notes to contextualize the monetary situation. We learn from Stephen Arkin's introductory essay in the Wordsworth edition of Sense and Sensibility, for example, that the value of the British pound should be multiplied by a factor of 50 to 100 in order to arrive at its modern equivalent in American doll: (viii). ${ }^{[6]}$ Therefore, the opening statement of Mansfield Park that Maria Ward Bertram was worth about 7,000 pounds when she married Sir Thomas $\mathrm{C}$ be taken to mean that she brought to the marriage a dowry, so to speak, of some $\$ 350,000$ to $\$ 700,000$. Of course, we are told that Maria Ward worked a very good arrangement for herself, because 10,000 pounds would have been more appropriate for an "equitable claim" to "the greatness . the match" with Sir Thomas (Austen Mansfield 3). Thus, a woman of Maria Ward's standing would need about half a million to a million dollars in the bank in order to be sufficiently desirable to the likes of Thomas Bertram.

But the question is reciprocal: does Thomas Bertram have the financial security to deserve an alliance that brings in Maria Ward's available capital? Perhaps the easier question is how much money Bertram has at his disposal, a sum which, at least in this particular instance, Austen neglects to inform us. However, James A. Downie believes that Bertram had something more than 5,000 pounds of annual income at his disposal, taking into consideration the earlier work of historian Trevor Lloyd and then adding a few of his own assumptions (74-75).

However, the precise details of Bertram's fortune are not so important in the interaction between Bertram and his niece Fanny as is the assumption that he simply wishes his estate to maintain its status quo, at the very minimum, and preferably to increase in wealth and influence. And if the questi is how Bertram strives to "make money make money," in the good-old-fashioned capitalist sense, then the portions of Anti-Oedipus that deal particularly with capitalism and its interrelation with the functions of desire are especially pertinent. But once again, it is necessary to return to the theoretical framework to make greater sense of Fanny's reticence.

A central feature of the Deleuze/Guattari project is demonstration that we individuals are not necessarily a unified primordial "voice" in asserting our desire, but rather a collocation of the huge number of forces that have gone into our socialization. This assumption may seem constraining in that it superficially argues that Fanny is not the master of her own destiny, but is actually quite liberating in positing that both Bertram as the "lord of the manor" and Fanny as the vulnerable and defensive young ward of the older and wealthier master are both subject to the same socializing forces. In reference to literary works such as Mansfield Park, though not specifically referencing Austen or her novels, Anti-Oedipus has this to say:

For reading a text is never a scholarly exercise in search of what is signified, still less a highly textual exercise in search of a signifier. Rather it is a productive use of the literary machine, a montage of desiring-machines, a schizoid exercise that extracts from the text its revolutionary force. (Deleuze and Guattari 106)

Because the human individual is not a primordial entity that arises from no prior influences, it is easier to think of both Fanny and Sir Thomas as complicated confabulations of their various socializing experiences. The same is true of Sir Thomas's Antigua plantation, which should not be taken some sort of primordial entity, but rather as a human construct that has been built through many interactions and which, in its current iteration, is simply a commodity that will soon be employed for the generation of new capital, new wealth, and of course, new familial influence and prominence

At this point it is helpful to reference the precise exchange between Bertram and Fanny. After Fanny has soundly rejected Crawford, the latter is unfazed and proceeds to ask Sir Thomas for her hand in marriage. Although we are not privy to this conversation, Sir Thomas reports that Crawford has had every reason to think that Fanny is merely being coy and intends to accept his proposal in due order. Fanny sets him right:

'Am I to understand,' said Sir Thomas, after a few moments silence, 'that you mean to refuse Mr Crawford?' / 'Yes, Sir.' / 'Refuse him?' / 'Yes, Sir.' / 'Refuse Mr Crawford! Upon what plea? For what reason?' / 'I - I cannot like him, Sir, well enough to marry him.' (252)

The conversation continues for several additional pages of text, with Sir Thomas simply refusing to see how Fanny could have the impertinence to reject a wealthy suitor. Gaining little ground, Sir Thomas eventually resorts to the sort of emotional battery that hitherto in the novel has been so characteristic of Aunt Norris:

Here is a young man of sense, of character, of temper, of manners, and of fortune, exceedingly attached to you, and seeking your hand in the most handsome and disinterested way; and let me tell you, Fanny, that you may live eighteen years longer in the world without being addressed by a man of half Mr Crawford's estate, or a tenth part of his merits. (255)

We may initially be persuaded that Sir Thomas equates certain personal traits with the possession of wealth, even though he doesn't really say that five portions of wealth are equal to a single portion of personal merit. Nevertheless, he makes a comparison of Crawford to other hypothetical suitor arguing that he is twice as rich as virtually any that Fanny would hitherto encounter, and ten times more meritorious. Thus, it is difficult to envision ar motive on the part of Sir Thomas other than an expansion of his empire, however indirect.

As is the case of the economic circumstances surrounding the families of Austen's novels, a motivated reader can also easily find ample speculatior on the nature of Sir Thomas's Antiguan property itself, such as Gareth Jones's "Where's the Capital? A Geographical Essay," and Thomas Piketty's Capital in the Twenty-First Century. As these and other writers have indicated, the details that Austen supplies to us are rather sketchy at best, whicl means that historic contextualization is enlightening in understanding what Austen herself understood about slavery. However, my own point is that the details are not so important as the assumption that Sir Thomas - or any aristocratic Englishman like him - would naturally have wanted his overseas property to at least hold steady in returns, and preferably to bring in more capital as time wore on. Such is surely the goal of any good capitalist. 
For this reason, the primary textual matter we should concern ourselves with in regard to Sir Thomas's overseas ventures is simply the phrase "som recent losses on his West India Estate" (19). Despite the fact that one may find historic contextualization in the details, as does Judith Terry is "Sir Thomas Bertram's 'Business in Antigua,'” we may additionally speculate that Sir Thomas spends the bulk of the first half of the novel in the West Indies so as to enhance its profitability. If he can do little about the price of sugar on the international market, or about shipping rates and the like, tr presumably his endeavors would focus on getting as much value out of his laborers as possible. Here again we can fund much in Deleuze/Guattari 1 describe the underlying assumptions:

Capital is indeed the body without organs of the capitalist, or rather of the capitalist being. But as such, it is not only the fluid and petrified substance of money, for it will give to the sterility of money the form whereby money produces money. It produces surplus value, just as the body without organs reproduces itself, puts forth shoots, and branches out to the farthest corners of the universe. (Deleuze and Guattari 10)

This passage implies that Sir Thomas is not so much a plantation owner or even traditional businessman as he is an individual who is programmed I his own Oedipalization to create surplus value. Naturally he wishes to wrest as much clear profit from the Antiguan estate as possible, but in the san vein, Fanny also wishes to wrest as much value as possible out of being a young lady of high ethical standards who finds Crawford entirely too immature and too inclined to ridicule those whom he considers himself intellectually superior, such as James Rushworth.

The above assumption may be the most startling one that can be made in an Anti-Oedipal reading of the novel, for it effectively states that the capitalist endeavors of a businessman are on par with the likewise "capitalist" endeavors of an individual simply attempting to maximize his or her place in the world. In the former sense, the commodity in question is sugar that can be sold for more revenue than that required to produce it. In the latter, the commodity is the individual who wishes to find as good a place in the world as possible with as little sacrifice as possible. In the case of Fanny Price, the capital investment involved in marrying a man such as Henry Crawford is simply too steep to make the transaction a desirable one. Fanny, after all, has her "price," but one that has little if anything to do with money or other estimations of material value. As one of Austen's more noble creations, she is an interesting contrast to Sir Thomas, who seemingly is always more conscious of the bottom line than of character.

The last statement is demonstrable because Sir Thomas is as wrong as he can be about Henry Crawford's character. Other wealthy young heirs ma: possess only a "tenth part of his merits," but if so, the landed youth of nineteenth-century England are a dissolute lot indeed! Crawford shows his mettle by pursuing and winning Maria Bertram, who is already married to James Rushworth. As the two run away to set up house, the rest of the Bertram family is scandalized and Sir Thomas is thoroughly chastised by his inability to initiate and/or encourage the sort of marital liaisons that can benefit his family's wealth and status.

Fanny, of course, is the beneficiary of this chastisement, and as the novel concludes we find her engaged and successfully married to her cousin Edward Bertram, the second son of Sir Thomas. Edward will be obliged to limp along on an annual salary between $\$ 35,000$ and $\$ 70,000$ in modern dollars, and he is not in line for property inheritance due to the laws of primogeniture, but he is nonetheless a man whom Fanny finds entirely suitabl as a soul-mate. More profitable for Sir Thomas would undoubtedly have been a marriage between Edward and Henry Crawford's sister Mary, who commands a 20,000-pound fortune (which, at a conservative investment return of 1,000 pounds per year, would supplement Edward's 700 pounds quite nicely). Mary Crawford is Edward's initial love-interest, but things never really gel between the two, meaning that Edward will have to make do with his position as a clergyman. And as if the matter needs overdetermination, Mary's callous statements late in the novel definitively assure Edwar that the beautiful and rich young woman is simply too morally lax to be his wife. Tom Bertram, meanwhile, has more or less recovered from a lifethreatening illness by the end of the novel, and we last see him as a twenty-six-year-old who "became what he ought to be, useful to his father, stea and quiet, and not living merely for himself" (371).

Whether this means that Tom will die unmarried and pass on the right of inheritance to his younger brother Edward is moot for the present discussic because Sir Thomas has precipitously passed into a new investment phase. Sir Thomas has wrested all the profit available from his overseas ventur as well as from advantageous marriages of his four children, which means that the time has come for disjunctive synthesis, in Deleuzian/Guattarian parlance. We observe this process most notably first in Sir Thomas's lecturing of Fanny, and a quotation from a relevant section of Anti-Oedipus will make the connection apparent:

When Oedipus slips into the disjunctive synthesis of desiring-recording, it imposes the ideal of a certain restrictive or exclusive use on them that becomes identical with the form of triangulation: being daddy, mommy, or child. This is the reign of the "either/or" in the differentiating function of the prohibition of incest: here is where mommy begins, there daddy, and there you are - stay in your place. (Deleuze and Guattari 75)

Of course, the subject is not literally incest, but rather one of retrenchment. Once the opportunity to gain steady and predictable gains from initial capitalist ventures has peaked, then what is the next step? Diversification may or may not be the future scenario, but anything is better than implosion.

The final synthesis in the Anti-Oedipal system is the conjunctive synthesis of consumption-consummation. Although Sir Thomas has been chastisec by the scandalous behavior of his daughter Maria, he compensates by acceding to the marriage of first-cousins Fanny and Edward. And even if the marriage would otherwise have been discouraged and probably disdained, Sir Thomas has relented to a new sense of "becomings," as the text makes clear:

It was a math which Sir Thomas's wishes had even forestalled. Sick of ambitious and mercenary connections, prizing more and more the sterling good of principle and temper, and chiefly anxious to bind by the strongest securities all that remained to him of domestic felicity, he had pondered with genuine satisfaction on the more than possibility of the two young friends finding their mutual consolation in each other for all that had occurred of disappointment to either. (379) 
This world of compromise is a world that especially favors the individual - or group of individuals - who have run counter to the desires of the entrepreneur who would have his kingdom built in a different and more opulent manner. To quote Deleuze/Guattari once more,

Should the rupture with families be taken as a sort of "familial romance" that would indeed bring us back again to families and refer us to an event or a structural determination inside the family itself? Or is this rather the sign that the problem must be raised in a completely different manner, because it is already raised elsewhere for the schizo himself, outside the family? Is history's signifier the dead father? (Deleuze and Guattari 89)

In terms of the last question, we must assume that it is a relative one. Has Sir Thomas's scheme for familial succession proceeded according to plar Clearly not: the elder son has shown no inclination to marry and carry on the dynasty; the most promising daughter has brought disgrace to the fam while her less promising sister has entered into a marriage of compromise; and the younger son and a female ward (actually, a niece by marriage) he failed to make suitable marriages of status and power, and instead have married each other.

But is he the "dead father," or merely an individual who has brokered the best deal in life he can manage while hoping for a better tomorrow? One ci argue the latter, particularly because the future of the family is still not certain. Tom may yet marry, younger sister Julia may produce offspring who possess such social brilliance that they reinvigorate the family fortune through equally brilliant marriages, and Edward and Fanny may do likewise. $T$ tale of the Bertrams is not finished, nor is it necessarily even compromised. But one thing perfectly clear is that the family's story has changed.

Once again, what does this have to do with slavery? One of my working assumptions in this paper, albeit unoriginal, is that Fanny's situation in Mansfield Park is an analogue of the slave's situation on Sir Thomas's plantation in Antigua. Although we never meet any of the slaves or even hear the name of an individual associated with the plantation, we nonetheless can infer by triangulation that the Bertram estate in Antigua must have undergone an evolutionary process similar to that of Fanny in her dealings with the family. This is pure speculation bordering on fantasy, of course, $k$ one can conceive of a plantation in which Sir Thomas can no longer trade out problem slaves - or else have his estate manager do so by proxy because the slave trade but not the institution of slavery has ended in the British Empire by the novel's 1814 publication. With less bargaining power Sir Thomas must settle for a slave coterie that has more bargaining power than they once had.

This point leads to the final insight that I will attribute as a possible hidden theme of Austen's - to wit, that Mansfield Park views slavery as an inherently unstable institution. If so, then the instability must result from the simple fact that the slaves themselves have their own desires and their own desire-production that cannot be subdued. This is in no way a melioration of the odious institution of slavery, and certainly in no way an argume that the slaves were anything other than victims. Yet, as Fanny's case shows, a person with no power can occasionally work a change in the world when the power of those who would oppress him or her has run its course. Moreover, an especially fortuitous occasion for change is when the free flow of capital has been stanched and there are those who, for one reason or another, resist the Oedipalization that would normally coerce them intc conformity. It is in the case of such deterritorializations, in Deleuzian/Guattarian terminology, that the power-brokers themselves are forced to adjust For after all, even the power-brokers are subject to the same deterritorializations and reterritorializations as those from whom they derive their capitc

Fanny's successful resistance of her family, then, may be taken as an analogue to the manner in which the slaves of Sir Thomas's estate may have improved their lot. If so, did the slaves hurt the family investment by agitating for better conditions and thereby narrowing the profit margin? Maybe and maybe not. After all, Sir Thomas's revamped estate may have turned into such an efficient operation that the family assured its holdings and profitability on the sugar market for generations to come. But whatever the case, the economic situation has been altered forever.

The fact remains that everything which occurs in Mansfield Park hinges on reversals and inherent instability. Sir Thomas Bertram may wish for a stat of affairs in which the family estate calmly and imperturbably passes from generation to generation in a state as unflinchingly solid as the magnificer portraits on the walls of his venerable mansion, but he has himself gamed the system. As Gareth Jones implies in a long essay critiquing Thomas Piketty's Capital in the Twenty-First Century, Bertram himself was likely the instigator of his own instability, which in turn could have had much broac ramifications. Why? Because the new way of doing things "came at the 'price' of near total dismantlement of the economic, social and cultural fabri of the colonies" (Jones 724). If I am reading Jones correctly, it would seem that the purchase of a slave plantation in Antigua, even if assumed to be relatively safe investment, would have been as ultimately disruptive to the family estate as the sale of those stately portraits in the ancestral mansior [7]

In conclusion, I will cede that a difficulty in arguing for an Anti-Oedipal reading of Mansfield Park is the rational judgment that Fanny displays throughout much of the novel. When everyone else in the family fails to discern Crawford's character shortcomings, she is quite astute in intuiting th the man can simply not be trusted as a potential husband. Such mature rationality would seemingly have little to do with the Anti-Oedipal as a philosophical rejection of the status quo in favor of the counter-intuitive and downright dangerous. Yet, the very fact that Fanny goes against her family's wishes is so overwhelmingly unlikely that it is hard to impute any motive other than a bit of irrationality that occasionally runs in parallel to he normally cool demeanor. She may be justified in rejecting Crawford, but her doing so is the end-result of a desire-production that runs counter to he socialization. Her principled stance is in no way condoned by any family member at the outset, and only begrudgingly by several of them (Edward al his father excluded) even after Crawford's nefariousness becomes glaringly obvious. If Crawford had not shown his true colors, the Bertram family's jaundiced estimation of Fanny would have continued, and she might have even been obliged to permanently extend her stay with her own dysfunctional nuclear family in Portsmouth. In short, Fanny does something inexplicable, but escapes further retaliation because the time happens $t$ be ripe for a disjunctive synthesis.

As for Edward Said's pronouncements on Mansfield Park, it is difficult to see how he is wrong, although I believe that I have offered an interesting footnote to his reading. To England's credit, the institution of slavery was abolished without 600,000 dead soldiers on the battlefield, as was the casi in America. But it is nonetheless difficult to see how Mansfield Park added any fire to the abolition argument, or how the characters of the novel can attributed with anything other than a fairly cavalier attitude toward the plight of the slaves themselves. At best, Austen deeply implies that the 
maintenance of a slave plantation is a hopeless cause if it must rely on an overseer on the model of a Mrs. Norris to effect its proper running. Perhar a further argument can be made that the many slave rebellions which occurred until the eventual abolition of slavery in the nineteenth century may have likewise arisen from a disjunctive synthesis that ultimately led to a connective synthesis, and finally, to the eradication of slavery. This would be very liberal and free-wheeling interpretation of slavery as it scantily appears in Austen's novel, but one that I feel is at least not contradicted by the text.

\section{Works Cited}

Arkin, Stephen. Introduction. Sense and Sensibility, by Jane Austen. 1811. Wordsworth Classics, 2000, pp. v-xv.

Austen, Jane. Mansfield Park. 1814. Wordsworth Classics, 2000.

Buchanan, Ian. Deleuze and Guattari's Anti-Oedipus. Continuum, 2008.

Deleuze, Gilles, and Felix Guattari. Anti-Oedipus. Translated by Robert Hurley, Mark Seem, and Helen R. Lane. Penguin Books, 1977.

Downie, James A. "Who Says She's a Bourgeois Writer? Reconsidering the Social and Political Contexts of Jane Austen's Novels." EighteenthCentury Studies, vol. 40, no. 1, 2006, pp. 69-84.

Fraiman, Susan. “Jane Austen and Edward Said: Gender, Culture, and Imperialism.” Critical Inquiry, vol. 21, no. 4, 1995 , pp. 805-821.

Jones, Gareth A. "Where's the Capital? A Geographical Essay." The British Journal of Sociology, vol. 65, no. 4, 2014, pp. 721-735.

Kitsi-Mitakou, Katherina. "Narratives of Absolutism in Jane Austen's Mansfield Park." Papers on Language and Literature vol. 49, no. 2, 2013, pp. 11 140.

Perkins, Moreland. “Mansfield Park and Austen's Reading on Slavery and Imperial Warfare.” Persuasions On-Line, vol. 26, no. 1, Winter 2005, www.jasna.org/persuasions/on-line/vol26no1/perkins.htm. Accessed Aug. 22, 2016.

Piketty, Thomas. Capital in the Twenty-First Century. Harvard University Press, 2014.

Said, Edward. Culture and Imperialism. Vintage, 1994.

Terry, Judith. "Sir Thomas Bertram's ‘Business in Antigua.'” Persuasions, vol. 17, 1985, pp. 97-105.

Wallace, David Shane. "The White Female as Effigy and the Black Female as Surrogate in Jane Schaw's Journal of a Lady of Quality and Jane Austen's Mansfield Park." Studies in the Literary Imagination, vol. 47, no. 2, Fall 2014, pp. 117-130.

\section{Notes}

1. My purpose here is not so much to "refute the refuters" of Said as it is to propose an alternate viewpoint. As an example of criticisms of Said": interpretation, one may consider Susan Fraiman's "Jane Austen and Edward Said: Gender, Culture, and Imperialism" to be a particularly tellin critique, succeeding as it does in demonstrating that Said's confusion of Maria Bertram's name with that of a character from Pride and Prejud reveals his superficial reading of the text in question. That may be, but neither I nor most other commentators would argue that Mansfield Par is a nuanced discussion of slavery. Textual details are simply not important to Said's argument, either in the functioning of the Antigua plantation's economy or in the given name of the elder Bertram daughter. As will become apparent, I argue that a vague perception of the dysfunctionality of slavery as an institution may well be the trace that Austen leaves for us in the text.

2. For those unfamiliar with the Deleuze/Guattari book, I should mention that my title "Sunbeams and Sugar Cane" is taken from a memorable quote in Anti-Oedipus which states that a celebrated German judge from the late nineteenth century had possessed "sunbeams in his ass," a tongue-in-cheek paraphrase of certain rambling pronouncements that the judge himself had made (Deleuze and Guattari 2). I make no accusations of insanity or even hyperbole for the Austen character Fanny Price. However, in a more muted sense, the allusion to Judge Schreber nonetheless points to a type of dissociation (or deterritorialization, in Deleuzian/Guattarian parlance) that, I argue, explains how Fanı Price may be a metaphor for the inherently unstable and unmanageable institution of slavery in Antigua.

3. Katerina Kitsi-Mitakou employs the Anti-Oedipal argument to demonstrate that Fanny has been "grafted into the Bertram family" as a semioutsider "who must gradually be trained into both paying off her infinite debt to her uncle and confusing his wishes for her desires" (117). Tha' is, she is socialized in such a way that she will learn the conscious and unconscious rules that temper individual desire and transforms the individual into acceptable members of family and society.

4. Many critics have commented on this relationship, but I will cite only a couple as examples. The view that Fanny Price can be taken as an analogue of the slave or indentured servant is well attested by the very title of David Shane Wallace's essay, "The White Female as Effigy and the Black Female as Surrogate in Jane Schaw's Journal of a Lady of Quality and Jane Austen's Mansfield Park." Wallace argues that Thomas Bertram, like others in the family, initially treated "his niece Fanny as little more than a perpetual servant to whom he has extended his benevolence in taking her from her poor parents and providing for her" (127). Moreland Perkins points out, in his essay "Mansfield Park and Austen's Reading on Slavery and Imperial Warfare," that Sir Thomas's tolerance for the treatment of Fanny by Mrs. Norris to the indifference c cluelessness he may conceivably have shown toward his Antiguan plantation overseer (para. 3).

5. Here, I refer to the well-known practice at the time of rewarding the bounty of captured enemy vessels to the commanders. As a newly-minter 
lieutenant, William will presumably be able to realize his dream of building a home for himself and his favorite sister with the income supplement.

6. Thomas Piketty offers a slightly different metric regarding the economics of Mansfield Park in his book Capital in the Twenty-First Century. But even though the precise equivalencies may be vague relative to current value, it should be apparent that even a 50-percent error of margin makes little difference in terms of creature-comfort if the alternatives are $\$ 350,000$ per year at one end of the scale, and $\$ 700,000$ per year at the other. The present author believes that he could probably squeeze by on either amount. The simple fact is that many of Austen's characte were very wealthy individuals by any metric.

7. Jones also writes that various occurrences and remarks in the novel hint that Sir Thomas possessed a "near desperate enthusiasm to get daughter and niece married [and] to secure or better his family's social standing. If capital and income ratios were stable in this period then th social, economic and political structure underpinning them appear to have been anything but" (726-7).

\section{Cite this Essay}

https://doi.org/10.20415/rhiz/033.e05

RHIZOMES ISSN 1555-9998 $\star 230$ East Hall Bowling Green State University Bowling Green, OH 43403

Editors: Ellen Berry and Carol Siegel. Reviews editor: Craig J. Saper. Technical editor: Helen J Burgess 